\title{
Deformation Zone Distribution of Continuous Extrusion Process
}

\section{Yong $\mathrm{Li}^{1}$, Yuxin Zhang ${ }^{1}$, Shiqiang Cui' ${ }^{2}$, Ruizhu Zhang ${ }^{1}$, Yi Zhong ${ }^{3}$}

${ }^{1}$ Dept. of Mechanical Engineering, North China University of Water Resources and Electric Power, Zhengzhou, Henan, 450045, China. E-mail: liyong@ncwu.edu.cn, zyx@ncwu.edu.cn, zhangruizhu@ncwu.edu.cn

${ }^{2}$ School of Materials Science and Engineer, Shanghai University, Shanghai, 200444, China. E-mail: cuishiqiang@shu.edu.com

${ }^{3}$ Kunming University of Science and Technology, Kunming, Yunnan, 650093, China. E-mail: liongkm@163.com

Experiments and numerical simulations were conducted to analyze the deformation zone of aluminum cable in the conform extrusion process, and complex metal flow is observed by finite element. In this report, detailed studies were especially focused on the width of the extruding dies mouth and leakage gap which influenced on the metal deformation, then the stress and strain distribution and contact force distribution of arbitrary step were obtained with respect to different technical parameters among random steps. Furthermore, the relationship between the parameters of $\Delta h$ and $W / H$ was given, indicating that the intense internal Shear Band-IISB and leak gap affect the metal forming behavior, and enlarge obviously plastic deformation zone in a certain range. Consequently, it's proper to be helpful for metal homogeneous deformation to reduce the entrance width of the extruding mold.

Keywords: Continuous extrusion, Deformation Zone Distribution, Mold Parameters

\section{Acknowledgments}

This work was supported by the National Youth Science Foundation of China (Grant No. 11404112). This paper was also supported by the college students' innovative project of North China University of Water Resources and Electric Power in 2014.

\section{References}

[1] B. MADDOCK. (1978). Aluminium, Vol. 3, pp. 207-211.

[2] J. TYROS. (1978). Theoretical and experimental study of the CONFORM metal forming process. Transaction of ASME.

[3] H. K. SLATER. (1988). Development Experience with the CONFORM continuous Extrusion process on Copper, Wire $J$.

[4] PENG Y. H., ZUO T. Y., PENG D. S., et al. (1993). Simulation of the CONFORM process numerical and experimental methods. Fourth International Conference on Technology of Plasticity, Beijing.

[5] PENG D S, YAO B Q, ZUO T Y, et al. The experimental simulation of deformation behavior of metals in the CONFORM process. Journal of Materials Processing Technology, Vol. 31 (1992), pp. 85 - 92.

[6] FUCHS. F. J. (1970). Hydrostatic Wire Extrusion, Wire J, pp. 105 - 113.

[7] FUCHS F, J, SEHMEHL G L. (1973) Int. Conform Hydrostatic Extrusion. Scotland.

[8] GREEN, D. British Patents No. 1370894, No. 1289482.

[9] GREEN, D. (1971). Hydrospin-A new concept of extrusion. Journal of the institute of metals, Vol. 99, pp. 76 81.

[10] AVITZUR, B. (1976). Methods of and apparatus for production of wire, United States Patent, US 3934446.

[11]AVITZUR, B. (1975). Extrolling: Combined Extrusion and Rolling. Wire J, Vol. 7, pp. 73 - 80.

[12] GRZINCIC, M., DJURDJEVIC, M., DIRNBERGER, F. (2013). Using of Thermal Analysis in the Industrial Practice-Consumption Reduction of Grain-Refinement Master Alloy and Optimization of Computer Simulation Results. Manufacturing Technology, Vol. 13, pp. 39 - 43.

[13] YUAN QINGNI, LU JIAN, PAN WEIJI, YUAN QINGYUN. (2014). Dynamics Analysis and Simulation of Roll Grinder Components. Manufacturing Technology, Vol. 14, pp. 600 - 607.

[14] KOBAYASHI, S., OH, S. I., ALTAN, T. (1989). Metal forming and the finite element method, Oxford University Press, New York. 
[15] OH, S. I., WU, W. T., TANG, J. P., et al. (1991). Capabilities and applications of FEM code DEFORM, the perspective of the developer. J of Materials Processing Technology. Vol. 27, pp. 25 - 42.

[16] WALTER, J. (1991). Application of finite element method in forging an industry perspective. J. Mater. Process Tech. Vol. 27, pp. 43 - 51.

[17] LEE, C. H., KOBAYASHI, S. (1973). New solutions to Rigid - Plastic Deformation Problems Using Matrix Method. Trans. ASME. J. Engr, IND. Vol. 95, pp. 865 - 869.

[18] OH, S. I. (1982). Finite Element Analysis of Metal Forming Problems with Arbitrarily Shaped Dies. Int. J. Mech. Sci, pp. 124:479.

[19]ETHERINGTON, C., et al. (1974). Conform-A new concept for the continuous extrusion forming of metals. Journal of Engineering for Industry. Vol. 8, pp. 893 - 900.

[20]JIANG, H. B., et al. (2010) Numerical Simulation on Deformation Process for H65 Brass Based on Continuous Extrusion. Hot Working Technology. Vol. 17, pp. 21 - 23, 28.

[21] POSPÍŠILOVÁ, I., VOJTĚCH, D. (2014). Effect of Extrusion on Mechanical Properties and Structures of Zn-Mg Alloys for Biomedical Applications. Manufacturing Technology, Vol. 14, pp. 417 - 421.

[22] ZHAI, W. T., PARK, CHUL B., et al. (2011). Nanosilica Addition Dramatically Improves the Cell Morphology and Expansion Ratio of Polypropylene Heterophasic Copolymer Foams Blown in Continuous Extrusion. Industrial \& Engineering Chemistry Research. Vol. 12, pp. 7282 - 7289.

[23]HE, Y. L., GAO, F., SONG, B. Y. (2010). Production of Very Fine Grained Mg-3\% Al-1\% Zn Alloy by Continuous Extrusion Forming (CONFORM). Advanced Engineering Materials. Vol. 9, pp. 843 - 847.

[24]ERDMANN, M. (2012). Continuous Extrusion Process. KGK-KAUTSCHUK GUMMI KUNSTSTOFFE. Vol. 65, pp. 16 - 19.

[25] POPESCU, I. N., BRATU, V., ROSSO, M. (2013). Designing and continuous extrusion forming of Al-Mg-Si contact lines for electric railway. Journal of Optoelectronics and Advanced, Vol. 15, pp. 712 - 717.

[26] HSIAO, WEN-TSE; LIN, JUI-CHANG; HUANG, et al.(2013). A Novel Continuous Extrusion Process to Fabricate Wedge-Shaped Light Guide Plates. International Journal of Polymer SCIENCE, No: 610132.

[27] GUAN, R. G., ZHAO, Z. Y., CHAO, R. Z., et al. (2012). Simulation of temperature field and metal flow during continuous semisolid extending extrusion process of 6201 alloy tube. Transactions of Nonferrous Metals Society of China, Vol. 22, pp.1182 - 1189.

[28]ZHAO, Y., SONG, B. Y., YUN, X. B., et al. (2012). Effect of process parameters on sheath forming of continuous extrusion sheathing of aluminum. Transactions of Nonferrous Metals Society of China, Vol. 22, pp.3073 - 3080.

[29]LU, J., et al. (1998). Computer modeling of the continuous forming extrusion process of AA6061 alloy. Journal of Materials Processing Technology, Vol. 79, pp. 200 - 212 